\title{
Neurology
}

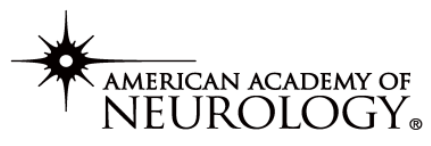

The most widely read and highly cited peer-reviewed neurology journal The Official Journal of the American Academy of Neurology

Neurology Publish Ahead of Print

DOI: 10.1212/WNL.0000000000012538

\section{Teaching Video Neuroimages: Hereditary Hyperekplexia Mimicking Tonic Seizures in an Infant}

Author(s):

Derek G. Neupert, M.D. ${ }^{1}$; Kevin M. Rathke, M.D. ${ }^{2}$; Mohamad A. Mikati, M.D. ${ }^{2}$

Equal Author Contributions:

These authors contributed equally to this work.

Neurology® Published Ahead of Print articles have been peer reviewed and accepted for publication. This manuscript will be published in its final form after copyediting, page composition, and review of proofs. Errors that could affect the content may be corrected during these processes. 


\section{Corresponding Author:}

Derek G. Neupert

derekneupert@yahoo.com

Affiliation Information for All Authors: 1. Department of Neurology, Duke University School of Medicine, Durham, NC. 2. Division of Pediatric Neurology, Department of Pediatrics, Duke University School of Medicine, Durham, NC.

\section{Contributions:}

Derek G. Neupert: Drafting/revision of the manuscript for content, including medical writing for content Kevin M. Rathke: Drafting/revision of the manuscript for content, including medical writing for content Mohamad A. Mikati: Drafting/revision of the manuscript for content, including medical writing for content

Number of characters in title: 62

Abstract Word count: 70

Word count of main text: 99

References: 2

Figures: 0

Tables: 0

Supplemental: 1 . Signed patient consent form permission to use photos, video, or other identifying materials. 2. Video 1

Search Terms: [ 60 ] All Epilepsy/Seizures, [ 62 ] EEG, [ 227 ] All Pediatric

Study Funding: The authors report no targeted funding

Disclosures: The authors report no disclosures relevant to the manuscript. 


\begin{abstract}
:
Hereditary hyperekplexia is a rare neurological disorder characterized by an exaggerated startle response with profound muscle stiffness. Given the nature of the spells, this condition is often misdiagnosed as epilepsy. Mutations in glycine receptors and transporters are the primary cause of this syndrome. We present an example of stimulus induced hyperekplexia captured on video EEG in a 7-week-old girl with compound heterozygous variants in the presynaptic glycine transporter gene SLC6A5.

\section{Case Summary:}

7-week-old full term girl with history of motor delay was referred for presumed daily tonic seizures since day 2 of life. Events were refractory to levetiracetam and phenobarbital. Family reported that episodes are triggered by tactile stimulation and resolve once the patient is held. We suspected hereditary hyperekplexia. On video EEG, four typical events were captured without epileptiform correlate (Video). She was transitioned to clonazepam with remarkable improvement. Genetic testing confirmed the diagnosis (compound heterozygous in the glycine transporter gene SLC6A5). Both variants have been reported previously in patients with hereditary hyperekplexia (pathologic variant: c.679+1G>T, IVS3+1G>T; and likely pathologic variant: c. $1640 \mathrm{~T}>\mathrm{C}$, p.F547S).
\end{abstract}




\section{Video 1 Legend:}

Video EEG of stimulus induced hyperekplexia event triggered by touching patient's abdomen.

Clinical episode is observed as sustained full body tonic stiffening and bilateral limb extension.

Event resolves once baby is held. No epileptiform correlate is observed on video EEG, only

muscle artifact.

Video 1-http://links.lww.com/WNL/B476

Teaching Slides-http://links.lww.com/WNL/B477 


\section{References:}

1. Carta E, Chung SK, James VM, Robinson A, Gill JL, Remy N, Vanbellinghen JF, Drew CJ, Cagdas S, Cameron D, Cowan FM, Del Toro M, Graham GE, Manzur AY, Masri A, Rivera S, Scalais E, Shiang R, Sinclair K, Stuart CA, Tijssen MA, Wise G, Zuberi SM, Harvey K, Pearce BR, Topf M, Thomas RH, Supplisson S, Rees MI, Harvey RJ. Mutations in the GlyT2 gene (SLC6A5) are a second major cause of startle disease. J Biol Chem. 2012 Aug 17;287(34):28975-85. doi: 10.1074/jbc.M112.372094. Epub 2012 Jun 14. PMID: 22700964; PMCID: PMC3436555.

2. Saini AG, Pandey S. Hyperekplexia and other startle syndromes. J Neurol Sci. 2020 Sep 15;416:117051. doi: 10.1016/j.jns.2020.117051. Epub 2020 Jul 20. PMID: 32721683. 


\title{
Neurology
}

\author{
Teaching Video Neuroimages: Hereditary Hyperekplexia Mimicking Tonic Seizures in an \\ Infant \\ Derek G. Neupert, Kevin M. Rathke and Mohamad A. Mikati \\ Neurology published online July 15, 2021 \\ DOI 10.1212/WNL.0000000000012538
}

This information is current as of July 15, 2021

Updated Information \&

Services

Subspecialty Collections

Permissions \& Licensing

Reprints including high resolution figures, can be found at:

http://n.neurology.org/content/early/2021/07/15/WNL.0000000000012538.f ull

This article, along with others on similar topics, appears in the following collection(s):

All Epilepsy/Seizures

http://n.neurology.org/cgi/collection/all_epilepsy_seizures

All Pediatric

http://n.neurology.org/cgi/collection/all_pediatric

EEG

http://n.neurology.org/cgi/collection/eeg_

Information about reproducing this article in parts (figures,tables) or in its entirety can be found online at:

http://www.neurology.org/about/about_the_journal\#permissions

Information about ordering reprints can be found online:

http://n.neurology.org/subscribers/advertise

Neurology ${ }^{\circledR}$ is the official journal of the American Academy of Neurology. Published continuously since 1951, it is now a weekly with 48 issues per year. Copyright (C) 2021 American Academy of Neurology. All rights reserved. Print ISSN: 0028-3878. Online ISSN: 1526-632X.

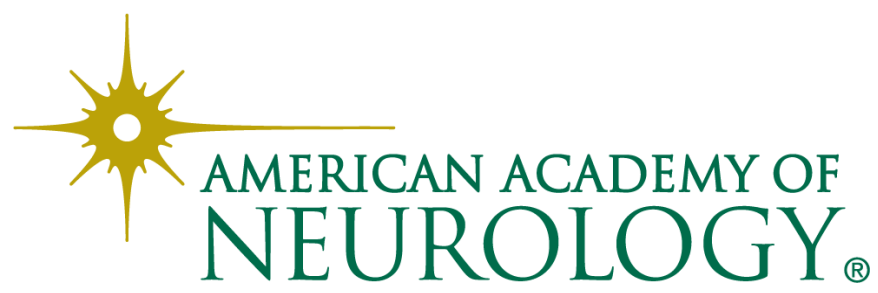

